\title{
Modification of Hippocampal Synaptic Proteins by Nitric Oxide-Stimulated ADP Ribosylation
}

\author{
Brian M. Sullivan, Stephen Wong, and Erin M. Schuman ${ }^{1}$ \\ Division of Biology \\ California Institute of Technology \\ Pasadena, California 91125
}

\begin{abstract}
Nitric oxide has been shown to be an important neuronal signaling molecule that participates in both behavioral and synaptic plasticity. To better understand the potential mechanisms by which NO regulates synaptic function, the ability of NO to stimulate the modification of synaptic proteins by ADP ribosylation was examined. Two NO donors, sodium nitroprusside and 3-morpholinosydnonimine, stimulated the ADP ribosylation of proteins at apparent molecular masses of $42,48,51,54$, and 74 $\mathbf{k D}$ in hippocampal synaptosomes. This stimulation was likely owing to the production of NO by the donors; ADP ribosylation was not stimulated by non-NO decomposition products of sodium nitroprusside, and quenching of superoxide anion did not inhibit Sin-1-induced ADP ribosylation. Experiments using $\mathrm{NAD}^{+}$that was radiolabeled on the nicotinamide moiety demonstrated that the modification of proteins of molecular masses of 30,33 , and $38 \mathrm{kD}$ are not true ADP ribosylation, whereas labeling of the 42-, 48-, 51-, 54-, and 74-kD proteins likely represent ADP ribosylation. Some of the substrates were brain specific ( 54 and $74 \mathrm{kD}$ ), whereas others ( 42 and $51 \mathrm{kD}$ ) were present in multiple nonbrain tissues.
\end{abstract}

\section{Introduction}

ADP ribosylation is the covalent attachment of an ADP-ribose moiety from $\mathrm{NAD}^{+}$to an amino acid

\footnotetext{
${ }^{1}$ Corresponding author.
}

of a substrate protein (Ueda and Hayaishi 1985). Examples of proteins that are substrates of this reaction include nuclear proteins such as histones and $G$ proteins of the $G_{S}$ of the $G_{I / O}$ families. $G_{S}$ and $G_{I / O}$ are modified by cholera and pertussis toxins, respectively (Gierschik 1992; Serventi et al. 1992). $G_{S}$ is ADP-ribosylated on an arginine residue, resulting in inhibition of its intrinsic GTPase activity, persistent association of GTP with the G protein, and constitutive activation of adenyl cyclase (Serventi et al. 1992). Conversely, ADP ribosylation of $G_{I / O}$ on a cysteine residue results in uncoupling of the $G$ protein from its receptor (Gierschik 1992) and constitutive inactivation of the $G$ protein. Histones are modified by an endogenous poly(ADP-ribosyl) synthetase (PARS) (Okayama et al. 1978) in response to DNA strand breaks (Cleaver and Morgan 1991). The diffusible gas nitric oxide (NO) stimulates PARS, possibly as a result of free radical-induced DNA damage (Zhang et al. 1994). These observations raise the possibility that ADP ribosylation may modify neuronal function. Recent evidence has suggested a role for endogenous ADP ribosyltransferases (ADPRTs) in synaptic plasticity. Blockade of ADPRT activity has been shown to inhibit the induction of long-term potentiation (LTP) (Schuman and Madison 1994), a form of activity-dependent synaptic plasticity in the hippocampus that may be involved in memory formation. In addition, LTP-inducing electrical stimuli modulate endogenous NO-stimulated ADP ribosylation in the rat hippocampus (Duman et al. 1993).

Inhibition of NO synthase, the enzyme that produces the diffusible gas NO, has also been demonstrated to inhibit LTP induction by some stimulation protocols (for review, see Schuman and Madison 1994). NO has a variety of downstream actions including stimulation of a soluble guanylyl cyclase to produce cyclic GMP (cGMP) (Southam

LEARNING \& MEMORY 3:414-424 @ 1997 by Cold Spring Harbor Laboratory Press ISSN1072-0502/97 \$5.00

$$
\begin{array}{llllllllllllllll}
L & E & A & R & N & I & N & G & \begin{array}{l}
\mathcal{Q} \\
414
\end{array} & M & E & M & O & R & Y
\end{array}
$$


and Garthwaite 1991) and S-nitrosylation of various proteins such as the NMDA receptor (Lei et al. 1992). In addition, NO stimulates an ADPRT in homogenates of the hippocampus (Schuman et al. 1994) and other brain areas (Williams et al. 1992). These observations suggest that release of NO may change synaptic efficacy, at least in part, by stimulating an ADPRT.

To begin to identify substrates of ADPRTs in the brain, and specifically in the synapse, the reaction was studied in vitro using rat hippocampal synaptosomes. Various synaptic proteins that have specific stimulation patterns, tissue distributions, and subcellular localizations were observed to be ADP-ribosylated. These results suggest that in addition to cGMP formation and $S$-nitrosylation, NO may modify synaptic function by stimulating the ADP ribosylation of the individual proteins associated with the synapse.

\section{Materials and Methods}

\section{ADP-RIBOSYLATION ASSAYS}

Male Sprague-Dawley rats (29-37 days old) were anesthetized with halothane and decapitated. Hippocampi were removed and placed into icecold artificial cerebrospinal fluid (119 mM NaCl, 2.5 mм KCl, $1.3 \mathrm{~mm} \mathrm{MgSo}_{4}, 2.5 \mathrm{~mm} \mathrm{CaCl}, 1.0 \mathrm{~mm}$ $\mathrm{NaH}_{2} \mathrm{PO}_{4}, 26.2 \mathrm{~mm} \mathrm{NaHCO}$, and $11.0 \mathrm{~mm}$ glucose) gassed with $95 \% \mathrm{O}_{2}$ and $5 \% \mathrm{CO}_{2}$. Rat hippocampal synaptosomes were prepared by the method of Carlin et al. (1980). Following preparation, synaptosomes were flash-frozen in liquid nitrogen and stored at $-70^{\circ} \mathrm{C}$. The $\mathrm{ADP}$-ribosylation reaction mixtures contained synaptosomal protein, $\mathrm{NAD}^{+}$ labeled with either ${ }^{32} \mathrm{P},{ }^{3} \mathrm{H}$, or ${ }^{14} \mathrm{C}$ at a final concentration of $25 \mu \mathrm{M} \mathrm{NAD}{ }^{+}$in an ADP-ribosylation buffer containing $1 \mathrm{~mm}$ EDTA, $0.5 \mathrm{~mm} \mathrm{MgCl}_{2}, 0.5 \%$ (vol/vol) Triton X-100, $10 \mathrm{~mm}$ isoniazid, $1 \mathrm{~mm}$ 3-acetylpyridine adenine dinucleotide (APAD), 0.1 mM 5'-guanylylimidodiphosphate (GPP[NH]P or GIDP) in a final reaction volume of $100 \mu$. The NO donors, sodium nitroprusside (SNP) and 3-morpholinosydnonimine (Sin-1), were prepared within an hour of use. The amounts of radioactivity and synaptosomal protein per sample were constant within an experiment, ranging between $4 \mu \mathrm{Ci}$ and $9 \mu \mathrm{Ci}$ of radioisotope and $80 \mu \mathrm{g}$ and $250 \mu \mathrm{g}$ of protein per sample between experiments. All stimulation data are expressed as a ratio to the nonstimulated (lacking NO) control value for a given experi- ment to normalize for differences in radioactivity and protein concentration between experiments. Percent inhibition data are expressed as a percentage of the amount of labeling of a protein in the presence of SNP, with the amount of labeling in the presence of SNP considered to be $0 \%$ inhibition. The percent inhibition is calculated, with the aid of ImageQuant analysis software as $100 \%-[100 \times$ (integrated counts in a band in the presence of inhibitor)/(counts in presence of SNP)]. In approximately half of the experiments, $10 \mathrm{~mm}$ thymidine was substituted for $1 \mathrm{mM}$ APAD. Because there was no appreciable difference between the results obtained with the two buffers, the data were combined. The reaction proceeded for $30 \mathrm{~min}$ at $37^{\circ} \mathrm{C}$ and was terminated by adding 1 $\mathrm{ml}$ of ice-cold $10 \%$ trichloroacetic acid (TCA) and centrifuging the samples at $12,300 \mathrm{~g}$ for $10 \mathrm{~min}$. The supernatant was aspirated; the pellet was washed once with ether and recentrifuged. Finally, the proteins were resolubilized by vigorous vortexing in a buffer containing $62 \mathrm{~mm}$ Tris-Hcl $(\mathrm{pH}$ $6.7), 0.3 \% \mathrm{SDS}$, and $20 \mathrm{~mm}$ DTT in a total volume of $100 \mu$. The samples were then subjected to SDSPAGE (Laemmli 1970) and autoradiography. The superoxide quenching system consists of two enzymes: $50 \mathrm{U} / \mathrm{ml}$ of superoxide dismutase (SOD), which catalyzes the reaction $2 \mathrm{O}_{2}{ }^{-}+2 \mathrm{H}^{+} \rightarrow$ $\mathrm{O}_{2}+\mathrm{H}_{2} \mathrm{O}_{2}$, and $350 \mathrm{U} / \mathrm{ml}$ of catalase, which catalyzes $2 \mathrm{H}_{2} \mathrm{O}_{2} \rightarrow \mathrm{O}_{2}+2 \mathrm{H}_{2} \mathrm{O}$. For ${ }^{3} \mathrm{H}$ experiments, $\mathrm{EN}^{3} \mathrm{HANCE}$ (NEN) was used to intensify the tritium signal.

\section{WESTERN BLOTS}

Proteins, labeled by ADP ribosylation as above, were transferred to nitrocellulose and then probed with GAP-43/B-50 affinity-purified rabbit polyclonal antisera (kindly provided by A. Beatte Oestreicher, University of Utrecht, The Netherlands). Primary antibodies were detected using goat antirabbit secondary antibodies conjugated to alkaline phosphatase (from Boehringer Mannheim).

\section{TISSUE DISTRIBUTION}

Tissues were dissected from halothane-anesthetized rats and placed in ice-cold sucrose buffer (containing $0.32 \mathrm{M}$ sucrose, $1 \mathrm{~mm} \mathrm{NaHCO}, 1 \mathrm{~mm}$ $\mathrm{MgCl}_{2}, 0.5 \mathrm{mM} \mathrm{CaCl}_{2}, 0.1 \mathrm{mM} \mathrm{PMSF}$, and $1 \mathrm{mg} /$ liter of leupeptin) immediately following decapitation. The tissue were then homogenized and centri-

$$
\text { n..... }
$$


fuged for $10 \mathrm{~min}$ at $1400 \mathrm{~g}$. The supernatant was saved, flash-frozen in liquid nitrogen, and stored at $-70^{\circ} \mathrm{C}$. A total of $80 \mu \mathrm{g}$ of protein was added to each experimental sample from each tissue.

\section{SUBCELLULAR LOCALIZATION}

Hippocampal synaptosomal proteins were ADP-ribosylated in ADP-ribosylation buffer, which contains $0.5 \%$ Triton $\mathrm{X}-100$, as above. Postsynaptic density proteins were pelleted by centrifuging the samples at $183,000 \mathrm{~g}$ for $2 \mathrm{hr}$ (Carlin et al. 1980). Subsequently, the supernatant, which was enriched for cytosolic proteins, was aspirated and precipitated with TCA as above. Both the cytosolic and membrane proteins were resuspended as above in preparation for SDS-PAGE. Amounts of the two samples that corresponded to identical amounts of precentrifugation starting material were loaded onto adjacent lanes of SDS-PAGE gels. Protein concentration was determined by the methods of Lowry (Lowry et al. 1951) or Bradford (1976) and ${ }^{32} \mathrm{P}$ was quantified by liquid scintillation counting and PhosphorImager analysis. Statistical significance was determined by one-tailed sign test or $t$-test as indicated. Data are expressed as mean \pm S.E.M.

\section{MATERIALS}

$\left[{ }^{3} \mathrm{H}\right.$-adenine-2,8]NAD ${ }^{+}$was from ICN; $\left[4^{3}{ }^{3} \mathrm{H}\right]$ nicotinamide $^{+}$NAD, $\quad\left[{ }^{14} \mathrm{C}\right.$-carbonyl $]$ nicotinamide $\mathrm{NAD}^{+}$, and $\left[\mathrm{U}_{-}{ }^{14} \mathrm{C}\right]$ adenine $\mathrm{NAD}^{+}$were from Amersham; Sin-1 was from Molecular Probes, sodium nitroferricyanide (SNP) was from Mallinckrodt and Sigma; potassium ferricyanide was from Fisher; SOD and catalase were from Sigma; molecular weight markers were from BioRad. All other reagents were from Sigma.

\section{LAB ANIMALS}

The experimental protocols for the use of laboratory animals were approved by the appropriate institutional review committee and meet the guidelines of the National Institutes of Health (NIH).

\section{Results}

BASAL AND NO-STIMULATED ADP RIBOSYLATION IN HIPPOCAMPAL SYNAPTOSOMES

Under control conditions, at least 10 different proteins in hippocampal synaptosomes of approxi- mate molecular masses of $42,46,48,50,51,54,69$, 74,95 , and $116 \mathrm{kD}$ were labeled by ${ }^{32} \mathrm{P}$-labeled $\mathrm{NAD}^{+}$(Fig. 1, Control). Addition of the NO donors Sin-1 or SNP enhanced labeling of the proteins at $42,51,54$, and $74 \mathrm{kD}$ in a concentration-dependent manner (Fig. 1, lanes 2-4, 8-10). Maximal stimulation of these proteins was observed with SNP (5.0 mM; lane 4) and Sin-1 (10 mm; lane 10); SNP usually produced slightly greater stimulation than Sin-1. The fold stimulation by NO, relative to control labeling, is presented in Table 1. A prominent protein at $38 \mathrm{kD}$ exhibited labeling that was stimulated more robustly by Sin-1 than by SNP. Its stimulation is also quantified in Table 1 . The ADP ribosylation of the $46-$ and $50-\mathrm{kD}$ proteins was frequently inhibited, rather than stimulated by NO. Stimulation of very faint proteins at $30,33,48,95$, and $116 \mathrm{kD}$ was occasionally observed but was not consistent enough to quantify.

When both Sin-1 and SNP decompose spontaneously in aqueous solution, they release NO and other products. SNP decomposes into $\left[\mathrm{Fe}\left(\mathrm{CN}_{5}\right]^{2-}\right.$ and $\mathrm{NO}$, and Sin-1 releases a superoxide anion $\left(\mathrm{O}_{2}{ }^{-}\right)$before liberating $\mathrm{NO}$ (Southam and Garthwaite 1991). For this reason, the stimulation of ADP ribosylation resulting from addition of either SNP or Sin-1 could be caused by products other than NO. To determine whether the SNP stimulation is owing to NO or another SNP product, old SNP that had been exposed to light at room temperature for $12 \mathrm{hr}$ was added to the reactions. Considering the short half-life of NO in aqueous conditions (Garthwaite and Boulton 1995), this solution should contain primarily $\left[\mathrm{Fe}\left(\mathrm{CN}_{5}\right)\right]^{2-}$. This NO-depleted SNP did not stimulate ADP ribosylation is synaptosomes (Fig. 1, lane 5). Similarly, the addition of potassium ferricyanide, a compound that is structurally similar to SNP but that lacks NO, did not stimulate ADP ribosylation (Fig. 1, lane 6; similar results were obtained in seven additional experiments). The question of whether superoxide production by Sin-1 contributes to the stimulation of ADP ribosylation was also addressed. A superoxide quenching system, consisting of $50 \mathrm{U} / \mathrm{ml}$ of SOD and $350 \mathrm{U} / \mathrm{ml}$ of catalase (Garthwaite et al. 1988), was added to a reaction mixture containing $1 \mathrm{~mm}$ Sin-1. If superoxide anion contributes to the Sin-1 stimulation, then the addition of SOD/CAT should decrease the labeling. This was only observed for the 38-kD protein (Fig. 1, lane 12), suggesting that superoxide contributes to the stimulation of this protein but does not modulate the other proteins. Similar results were obtained in ex-

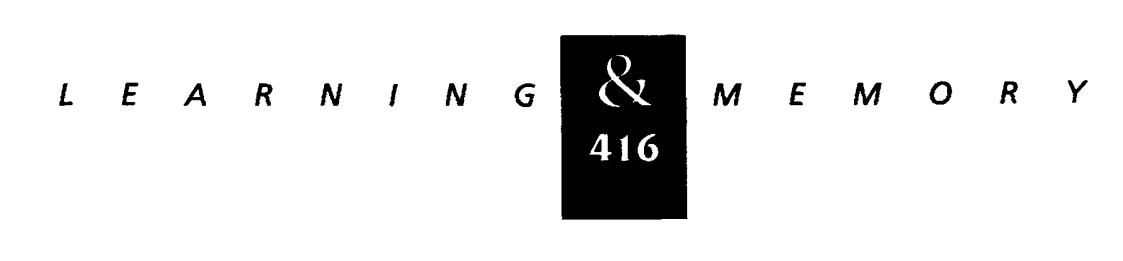




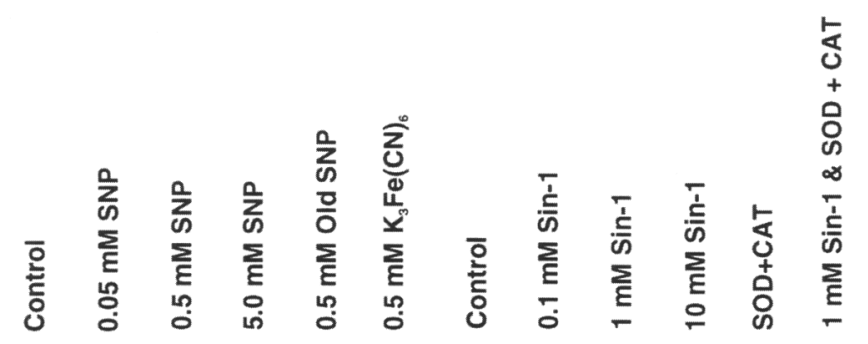

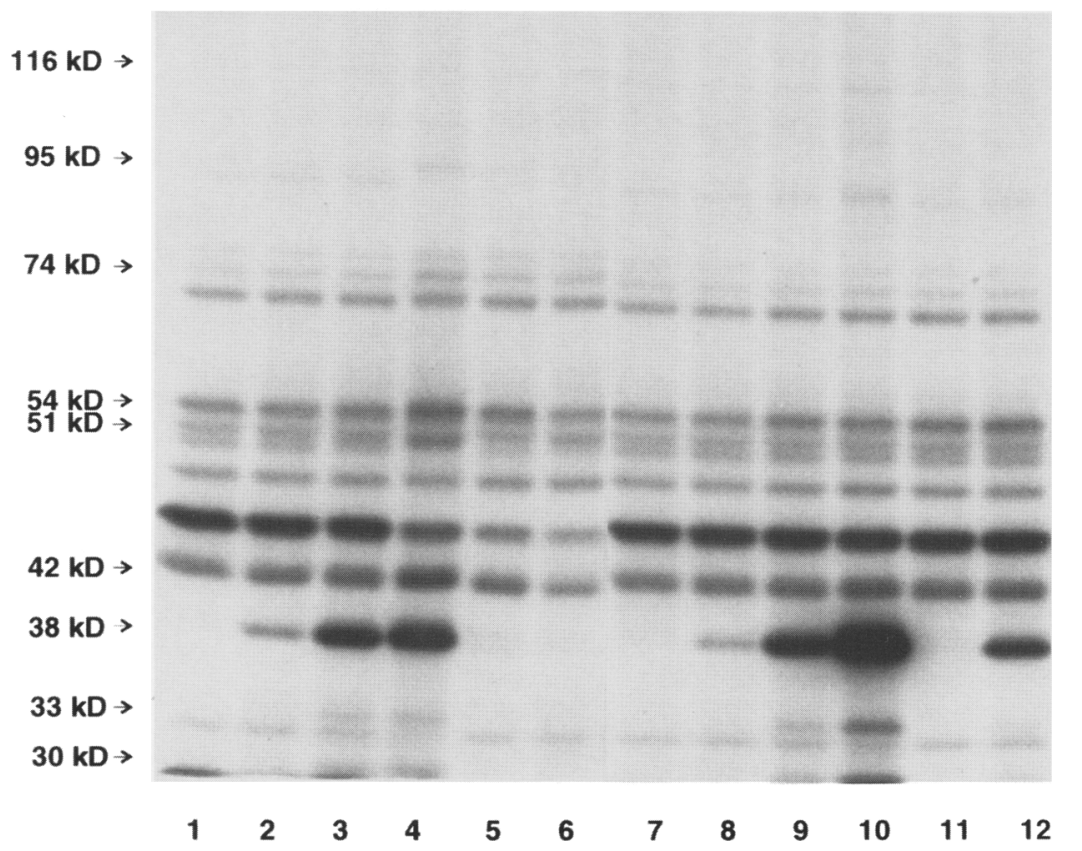

Figure 1: Basal and NO-stimulated ADP ribosylation of proteins in hippocampal synaptosomes. Hippocampal synaptosomal proteins were ADP-ribosylated as described in Materials and Methods in the presence of ${ }^{32} \mathrm{P}$-labeled $\mathrm{NAD}^{+}$. Two NO donors, SNP (lanes 2-4) and Sin-1 (lanes 8-10), were added to the reaction mixtures at the indicated concentrations resulting in the enhanced ADP ribosylation of proteins at 38,42 , $51,54,74,95$, and $116 \mathrm{kD}$. The addition of light-inactivated SNP (old SNP, lane 5) or potassium ferricyanide $\left(\mathrm{K}_{3} \mathrm{Fe}(\mathrm{CN})_{6}\right.$, lane 6) did not stimulate the ADP ribosylation of substrates. The addition of a superoxide quenching system (lanes $11,12)$ to $1 \mathrm{~mm}$ Sin-1-treated reactions reduced the stimulation of the $38-\mathrm{kD}$ protein but did not significantly affect the other substrates.

periments in which $10 \mathrm{~mm}$ Sin-1 was used with the superoxide quenching system (data not shown; $n=5$ ).

The sensitivity of the NO-stimulated ADP ribosylation to nicotinamide and novobiocin, inhibitors of ADPRTs (Rankin et al. 1989), was also exam-

Table 1: Summary of NO donor effects on ADP ribosylation of hippocampal substrates

\begin{tabular}{lccccccc}
\hline \multirow{2}{*}{$\begin{array}{l}\text { Molecular } \\
\text { mass }(\mathrm{kD})\end{array}$} & \multicolumn{3}{c}{ Sin-1 (mM) fold stimulation } & & \multicolumn{3}{c}{ SNP (mM) fold stimulation } \\
\cline { 2 - 3 } \cline { 6 - 8 } & 0.1 & 1 & 10 & & 0.05 & 0.5 & 5.0 \\
\hline 38 & $2.37^{*}$ & $20.58^{*}$ & $149.36^{*}$ & & $2.43^{*}$ & $12.85^{*}$ & $25.68^{*}$ \\
& $(7 / 8)$ & $(8 / 8)$ & $(8 / 8)$ & & $(8 / 8)$ & $(11 / 11)$ & $(13 / 13)$ \\
& 0.97 & 1.06 & $1.29^{*}$ & & 0.99 & 1.00 & 1.25 \\
51 & $(3 / 9)$ & $(6 / 9)$ & $(9 / 9)$ & & $(3 / 8)$ & $(4 / 12)$ & $(10 / 14)$ \\
& 1.14 & $1.27^{*}$ & $1.42^{*}$ & & 0.96 & $1.30^{*}$ & $1.70^{*}$ \\
54 & $(6 / 9)$ & $(8 / 9)$ & $(7 / 8)$ & & $(3 / 9)$ & $(11 / 12)$ & $(14 / 14)$ \\
& 1.06 & 1.07 & 1.18 & & 0.96 & 1.04 & $1.44^{*}$ \\
74 & $(4 / 8)$ & $(4 / 8)$ & $(5 / 7)$ & & $(3 / 8)$ & $(7 / 11)$ & $(13 / 13)$ \\
& 1.04 & $1.12^{*}$ & $1.27^{*}$ & & 0.97 & 1.17 & $2.00^{*}$ \\
& $(4 / 8)$ & $(7 / 8)$ & $(7 / 8)$ & & $(3 / 9)$ & $(9 / 12)$ & $(14 / 14)$ \\
\hline
\end{tabular}

The values shown are the mean-fold stimulation in the presence of NO donor relative to control. (A value of 1 indicates no stimulation). The values in parentheses indicate the number of experiments in which any stimulation was observed; the mean values were calculated including all individual experiments. Significance at $P<0.05$ is indicated by an asterisk $\left({ }^{*}\right)$.

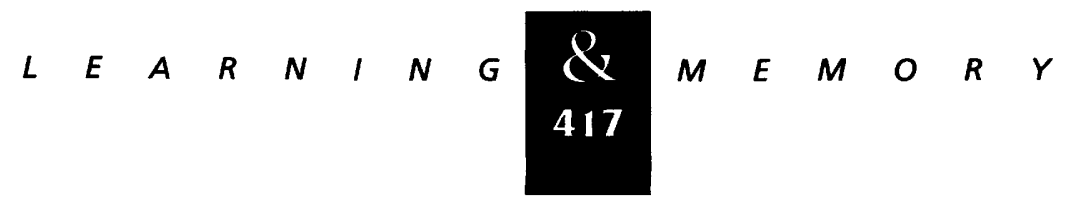


ined. Nicotinamide (10 $\mathrm{mm}$ or $100 \mathrm{~mm}$ ) reduced the NO donor-stimulated ADP ribosylation of the 42-, 46-, 51-, and 54-kD proteins (mean percent inhibition of labeling in the presence of $0.5 \mathrm{~mm}$ SNP by $10 \mathrm{~mm}$ or $100 \mathrm{~mm}$ nicotinamide, respectively: $42 \mathrm{kD}, 24.0 \pm 0.06 \%$ or $52.1 \pm 0.13 \%$; $46 \mathrm{kD}$, $19.8 \pm 0.09 \%$ or $69.0 \pm 13.3 \% ; 51 \mathrm{kD}, 23.4 \pm 14.4 \%$ or $56.8 \pm 18.1 \% ; 54 \mathrm{kD}, 16.3 \pm 13.8 \%$ or $54.3 \pm$ 21.9\%; $n=3$ for all conditions) (Fig. 2). Novobiocin $(0.5,1$, or $2 \mathrm{~mm})$ also attenuated the NO-stimulated modification of the 42-, 46-, 51-, 54-, and $74-$ $\mathrm{kD}$ substrates (mean percent inhibition of labeling in the presence of $0.5 \mathrm{~mm} \mathrm{SNP}$ by $0.5 \mathrm{~mm}$ or $2 \mathrm{~mm}$ Novobiocin, respectively: $42 \mathrm{kD}, 13.0 \pm 7.0 \%$ or $20.7 \pm 7.2 \%$; $46 \mathrm{kD}, 6.6 \pm 10.9 \%$ or $35.3 \pm 11.9 \%$; $51 \mathrm{kD}, 10.6 \pm 19.6 \%$ or $48.1 \pm 5.6 \%$; $54 \mathrm{kD}$,

A

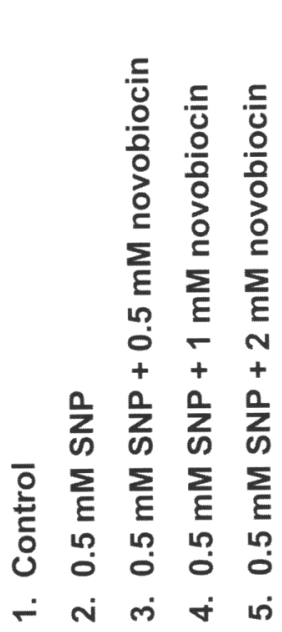

B
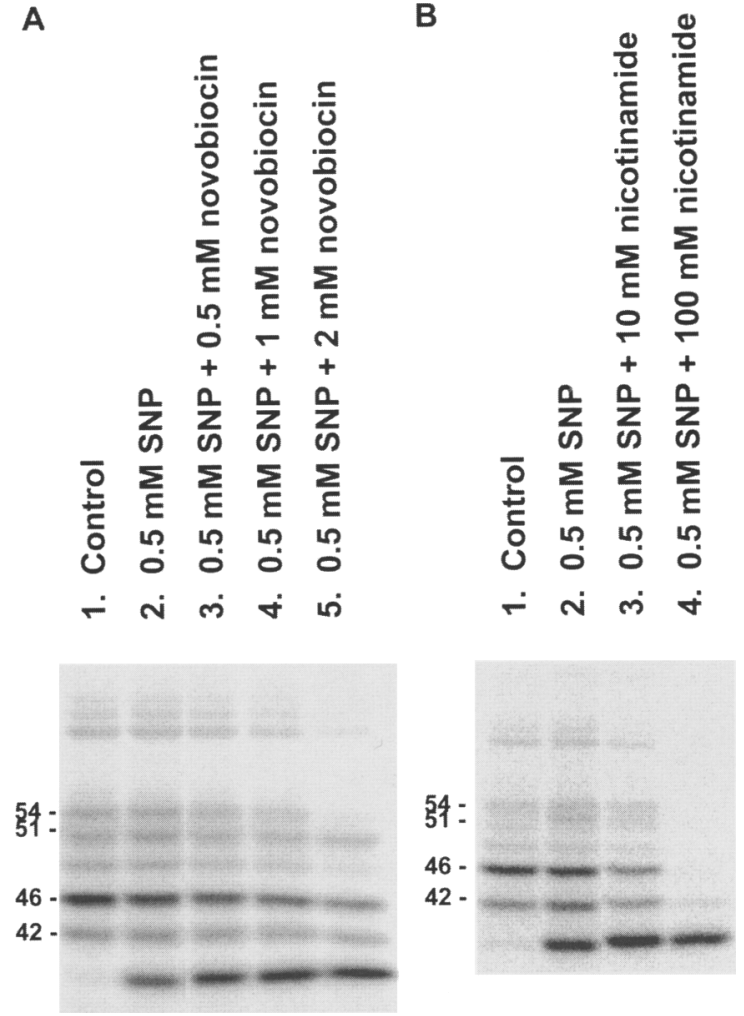

Figure 2: NO-stimulated ADP ribosylation of substrates is attenuated by inhibitors of mono ADP ribosylation. Shown are sample Phosphorlmager images of experiments that show the clearest example of the sensitivity of NO-stimulated ADP ribosylation to two inhibitors of ADP ribosylation, novobiocin, and nicotinamide. (A) Novobiocin produced a concentration-dependent inhibition of SNP-stimulated substrates at 42, $46,51,54$, and $74 \mathrm{kD}$. (B) Nicotinamide produced a concentration-dependent inhibition of SNP-stimulated substrates at $42,46,51$, and $54 \mathrm{kD}$.
$12.8 \pm 12.0 \%$ or $74.4 \pm 6.2 \% ; 74 \mathrm{kD}, 0.0 \pm 19.7 \%$, or $56.9 \pm 5.3 \% ; n=$ at least 3 for all conditions). The sensitivity to other inhibitors of ADP ribosylation could not be determined owing to independent effects of the solvents.

\section{DOES THE MODIFICATION OF THE SUBSTRATES REPRESENT TRUE ADP RIBOSYLATION?}

The protein glyceraldehyde-3-phosphate dehydrogenase (GAPDH) was originally reported to be a substrate of NO-stimulated ADP ribosylation (Brüne and Lapetina 1989, 1990; Duman et al. 1991; Dimmeler et al. 1992; Kots et al. 1992; Zhang and Snyder 1992). Subsequent studies (McDonald and Moss 1993), however, have shown that a novel $\mathrm{NAD}^{+}$metabolite that includes the nicotinamide moiety of $\mathrm{NAD}^{+}$in addition to the ADP-ribose moiety is added to GAPDH. The physiological relevance, if any, of this autocatalytic (Dimmeler et al. 1992; Kots et al. 1992; Zhang and Snyder 1992) reaction is unknown. Does the modification of hippocampal proteins described here reflect true ADP ribosylation? To address this issue, $\mathrm{NAD}^{+}$was utilized, which had been radioactively labeled on the nicotinamide moiety with either ${ }^{14} \mathrm{C}$ or ${ }^{3} \mathrm{H}$. The nicotinamide group is not added to the protein in an authentic ADP-ribosylation reaction (Ueda and Hayaishi 1985). Little labeling of proteins was observed when $\left[4^{3} \mathrm{H}\right]$ nicotinamide $\mathrm{NAD}^{+}$was added to synaptosomal protein in a reaction mixture lacking NO donors (Fig. 3, lane 1; data not shown; $\boldsymbol{n}=3$. In the presence of $1 \mathrm{~mm} \mathrm{Sin-1}$ (Fig. 3, lane 2), however, there was labeling of the proteins at 30,33 , and $38 \mathrm{kD}$, demonstrating that their labeling does not represent true ADP ribosylation. Lanes 3 and 4 of Figure 3 show the results of samples that were treated the same as those in lanes 1 and 2, respectively, except $\left[{ }^{3} \mathrm{H}\right.$-adenine-2,8] $\mathrm{NAD}^{+}$was used. As expected, the pattern of labeling was similar to the experiments where ${ }^{32} \mathrm{p}$-labeled $\mathrm{NAD}^{+}$was used. Similar experiments using ${ }^{14} \mathrm{C}$-labeled $\mathrm{NAD}^{+}$ yielded essentially the same results (data not shown; $n=2$ ).

\section{TISSUE DISTRIBUTION AND SUBCELLULAR LOCALIZATION OF THE SUBSTRATES}

TISSUE DISTRIBUTION

Various rat tissues including spleen, penis, skeletal muscle, heart, and liver were homogenized

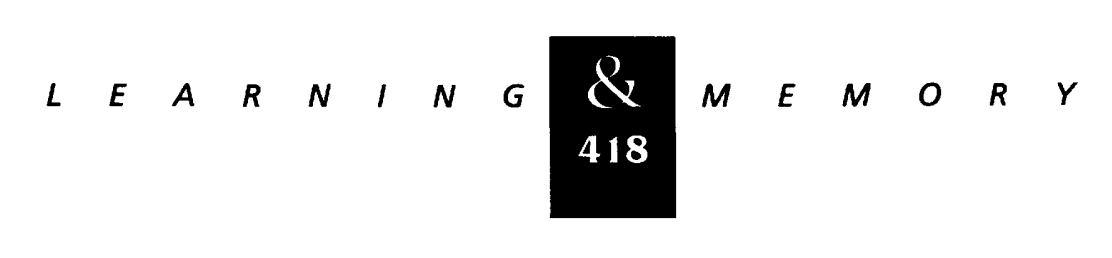




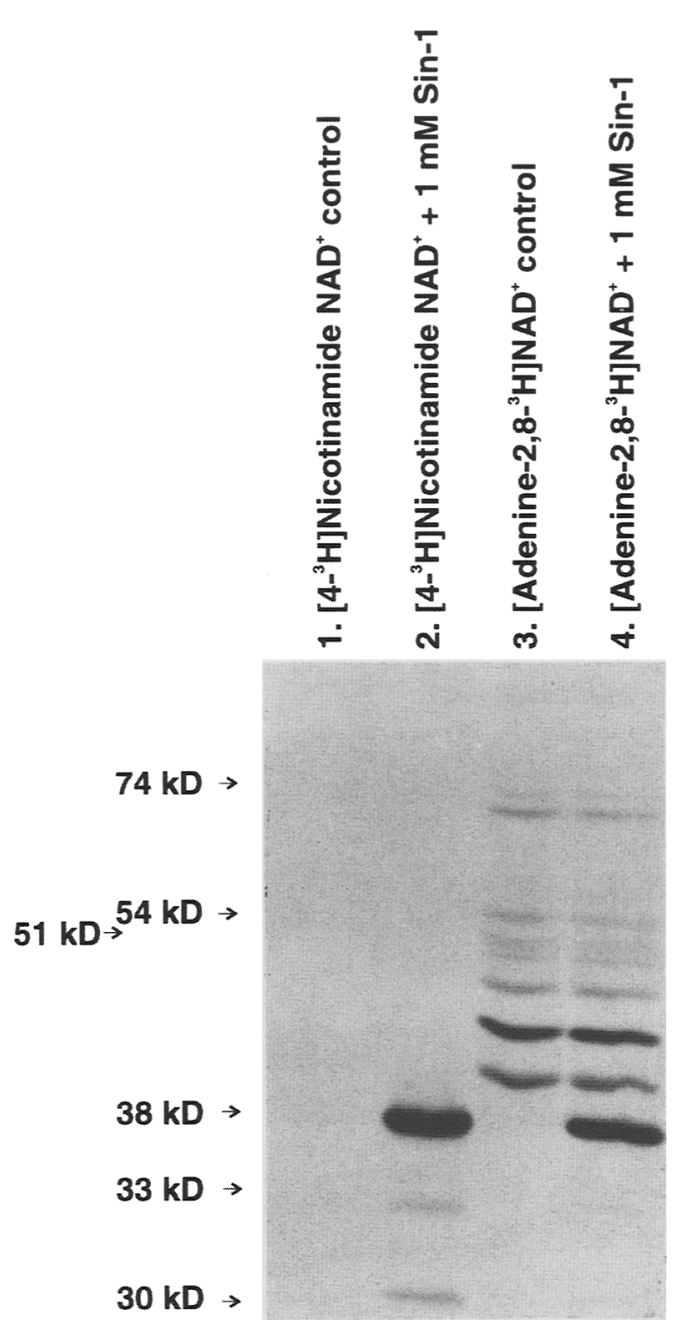

Figure 3: The majority of hippocampal substrates are modified by ADP ribosylation. Control reactions conducted in the presence of $\mathrm{NAD}^{+}$labeled on the nicotinamide moiety $\left(\left[4-{ }^{3} \mathrm{H}\right]\right.$ nicotinamide $\left.\mathrm{NAD}^{+}\right)$did not result in the detectable labeling of any substrates (lane 1). The addition of $1 \mathrm{~mm}$ Sin- 1 to nicotinamide-labeled NAD ${ }^{+}$ reactions resulted in the labeling of proteins at 30,33 , and $38 \mathrm{kD}$, indicating that these substrates are not modified by true ADP ribosylation (lane 2). In a separate set of reactions using $\mathrm{NAD}^{+}$labeled on the adenine moiety $\left(\left[{ }^{3} \mathrm{H}\right.\right.$-adenine-2,8]NAD $\left.{ }^{+}\right)$, a different set of proteins of molecular masses of $42,46,48,51,54$, and $74 \mathrm{kD}$ were labeled under control conditions (lane 3 ). The lack of labeling of these same proteins in lanes 1 and 2 indicates that these proteins are labeled by true ADP ribosylation.

and labeled by ADP ribosylation as described in Materials and Methods $(n=3)$. Hippocampal homogenate and homogenate made from forebrain (including the hippocampus) were also examined $(n=3)$. The same amount of protein was used for each tissue sample, permitting an analysis of the brain and tissue specificity of the various substrates by comparing the absolute amounts of labeled protein across samples. An example of the patterns of labeling observed for the rat spleen, penis, and skeletal muscle are presented in Figure 4B with the pattern from hippocampal synaptosomes shown in Figure $4 \mathrm{~A}$ as a reference. The quantified data are presented in Table 2. Overall, the pattern of labeling in the various tissues was similar to that in the brain, with some notable differences. Although it is unclear whether the labeled proteins observed in the various tissues are identical, proteins of 38,42 , and $51 \mathrm{kD}$ appeared in all of the tissues examined.

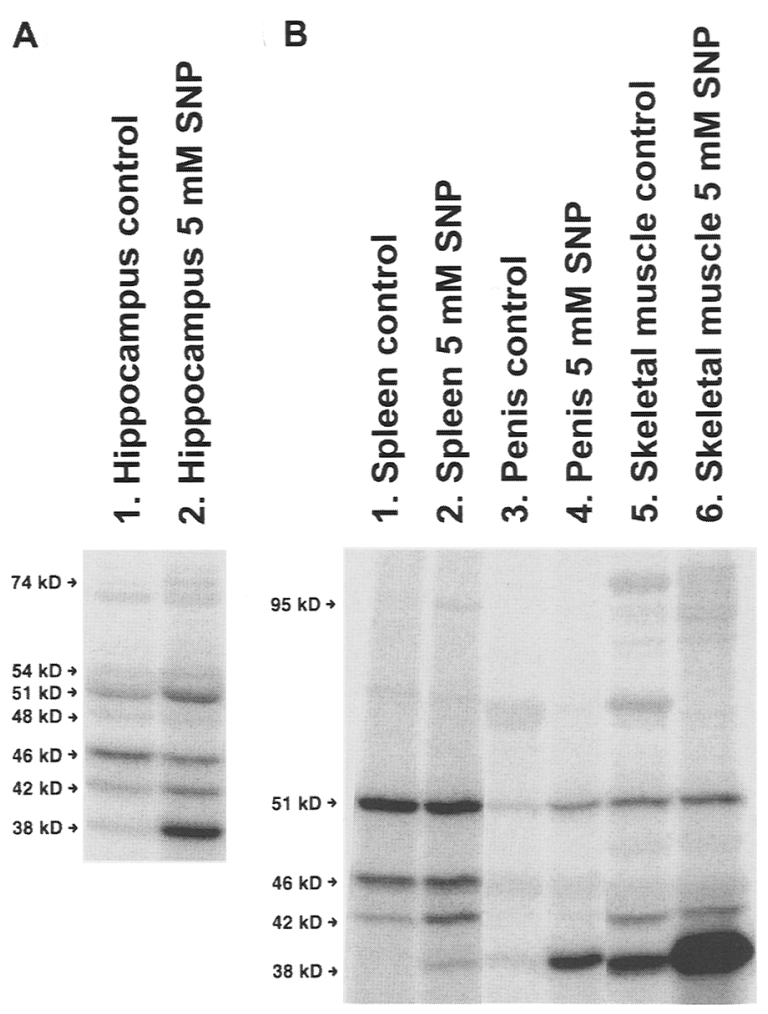

Figure 4: ADP-ribosylation substrates are present in both neural and non-neural tissue. (A) Control (lane 1) and SNP-stimulated ADP ribosylation (lane 2) in hippocampal synaptosomes are shown for reference. (B) ADPribosylation substrates in various non-neural tissues. In spleen homogenate (lanes 1,2), ADP ribosylation of 38-, 42-, 46-, 51-, and 95-kD proteins were frequently enhanced by SNP. In penis homogenate (lanes 3,4) ADP ribosylation of 38-, 42-, and 51-kD proteins were frequently enhanced by SNP. In skeletal muscle homogenate (lanes 5,6) ADP ribosylation of 38-, 42-, and 51kD proteins were frequently enhanced by SNP; in addition, there was substantial labeling of the $38-\mathrm{kD}$ protein in the absence of the NO donor.

$$
\begin{array}{llllllll}
L & E & A & R & N & I & N & G \\
419 & \mathcal{Q} & M & E & M & O & R & Y
\end{array}
$$




\section{Sullivan et al.}

Table 2: Summary of NO-stimulated ADP ribosylation in hippocampal and other tissues

\begin{tabular}{|c|c|c|c|c|c|c|c|}
\hline $\begin{array}{l}\text { Molecular } \\
\text { mass }(k D)\end{array}$ & $\begin{array}{l}\text { Hippocampal } \\
\text { homogenate }\end{array}$ & $\begin{array}{c}\text { Forebrain } \\
\text { homogenate }\end{array}$ & Penis & $\begin{array}{l}\text { Skeletal } \\
\text { muscle }\end{array}$ & Heart & Spleen & Liver \\
\hline \multirow[t]{2}{*}{38} & $5.10^{*}$ & $1.92^{*}$ & $12.47^{*}$ & $12.22^{*}$ & 12.61 & 2.10 & $10.48^{*}$ \\
\hline & 1.47 & 2.30 & 0.89 & 14.21 & 0.99 & 0.79 & 0.61 \\
\hline \multirow[t]{2}{*}{42} & $1.64^{*}$ & 1.13 & 1.29 & 1.49 & 1.27 & 1.79 & $2.16^{*}$ \\
\hline & 1.31 & 2.05 & 0.37 & 2.94 & 0.52 & 1.13 & 0.41 \\
\hline \multirow[t]{2}{*}{51} & 1.24 & 0.86 & $3.00^{*}$ & $1.37^{*}$ & 1.16 & $0.84^{*}$ & 1.10 \\
\hline & 1.79 & 2.23 & 0.38 & 1.91 & 4.51 & 2.66 & 2.71 \\
\hline 54 & - & - & - & - & - & - & - \\
\hline 74 & $\begin{array}{l}0.82 \\
6.70\end{array}$ & - & - & - & - & - & - \\
\hline
\end{tabular}

The tissue distribution of basal and NO-stimulated ADP ribosylation are shown for five different proteins in various tissues. The top number of each pair represents the average-fold stimulation in the presence of $5 \mathrm{~mm}$ SNP, relative to control levels of ADP ribosylation in the same tissue, as in Table 1. The bottom number of each pair represents the fold enrichment of that band in that tissue compared to hippocampal synaptosomes. This bottom number was calculated as the ratio of the amount of the band in the indicated tissue, without NO donor, to the amount of labeling of the band at the same molecular mass, also without NO donor, in hippocampal synaptosomes. A value of 1.00 indicates no difference. (-) No labeling was observed. Asterisks $\left(^{*}\right)$ indicate significance at the $P<0.05$ levels.

Each of these proteins was stimulated by $5 \mathrm{~mm}$ SNP in at least one of the tissues examined. A $46-\mathrm{kD}$ protein was seen in all of the brain samples as well as in the liver and spleen, and a faint $44-\mathrm{kD}$ protein appeared in skeletal muscle, heart, and penis. The 54 and $74-\mathrm{kD}$ proteins were present in all of the brain samples, although the high background in the brain homogenates made them difficult to quantify. They were not, however, discernable in any of the other tissues.

\section{SUBCELLULAR LOCALIZATION}

The enrichment of the enzyme activity and the substrates in various subcellular fractions were quantified by conducting subcellular fractionation either before or after the NO-stimulation ADP-ribosylation reaction. In each experiment the amount of radioactivity incorporated into a particular molecular weight band was quantified by PhosphorImager analysis. When tissues were fractionated before the ADP-ribosylation reaction, the labeling of proteins at apparent molecular masses of 42, 46, and $51 \mathrm{kD}$ was enriched in hippocampal synaptosomes compared with hippocampal homogenate (Table 3). When hippocampal synaptosomes were further separated into postsynaptic density (PSD) (Carlin et al. 1980) and non-PSD fractions, labeling of the $46-$ and $51-\mathrm{kD}$ proteins was significantly enriched in the non-PSD fraction compared with the
PSD (Table 3). Because the distribution of the ADPRT enzyme in the synaptosome, PSD, and cytosol fractions relative to the homogenate is not known, it is unclear whether the observed differences result from a differential distribution of the substrates, the enzyme, or both. However, when the synaptosome fraction is separated into PSD and non-PSD fractions after the ADP-ribosylation reaction, most of the labeled proteins are associated with the non-PSD fraction compared with the PSD (data not shown), suggesting that most of the substrates of ADP ribosylation are not tightly associated with the PSD either before or after modification.

\section{SUBSTRATES}

The possibility that one of the ADP-ribosylation substrates is the growth-associated protein- 43 (GAP-43; B-50), which has been reported by others to be ADP-ribosylated (Coggins et al. 1993; Philibert and Zweirs 1995), was examined. GAP-43 runs in SDS-PAGE gels at between 43 and $50 \mathrm{kD}$ depending on the density of the acrylamide polymer matrix (Gower and Rodnight 1982; Oestreicher et al. 1984; Benowitz et al. 1987). Proteins were radioactively labeled by ADP ribosylation using ${ }^{32} \mathrm{P}$-labeled $\mathrm{NAD}^{+}$in the absence (Fig. 5, lane 3) or presence (Fig. 5, lane 4) of $5 \mathrm{~mm} \mathrm{SNP} \mathrm{(exactly} \mathrm{as} \mathrm{those}$ in Fig. 1, lanes 1 and 4, respectively). They were

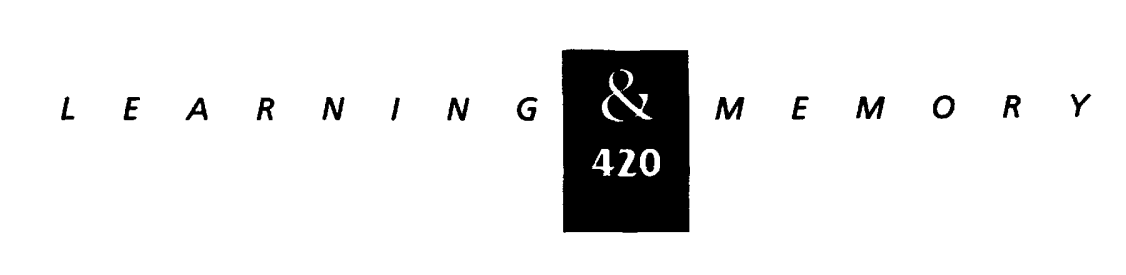


Table 3: ADPRT activity in the presence of $5 \mathrm{~mm}$ SNP is preferentially associated with certain subcellular fractions

\begin{tabular}{lcccc}
\hline \multirow{2}{*}{$\begin{array}{l}\text { Molecular } \\
\text { mass (kD) }\end{array}$} & $\begin{array}{c}\text { Synaptosome } \\
\text { (fmoles/mg per min) }\end{array}$ & \begin{tabular}{c} 
Synaptosomes \\
\cline { 3 - 5 }
\end{tabular} & $\begin{array}{c}\text { Pomogenate } \\
\text { (fmoles/mg per min) }\end{array}$ \\
\hline 42 & $2.93 \pm 0.14^{*}$ & $1.40 \pm 0.10$ & $2.49 \pm 0.18$ & $2.29 \pm 0.02$ \\
46 & $1.49 \pm 0.10^{*}$ & $0.70 \pm 0.08$ & $0.74 \pm 0.04$ & $1.24 \pm 0.05^{*}$ \\
51 & $1.86 \pm 0.04^{*}$ & $1.21 \pm 0.10$ & $0.71 \pm 0.02$ & $1.12 \pm 0.04^{*}$ \\
\hline
\end{tabular}

Numbers represent $\mathrm{NO}$-stimulated incorporation of radioactivity in fmoles/mg per min for each molecular mass, calculated using Phosphorlmager analysis. Statistical comparisons were made for each molecular mass comparing synaptosome and homogenate or PSD and cytosol. Asterisks $\left(^{*}\right)$ indicate significance at the $P<0.05$ level; $n=3$ for all conditions.

then transferred to nitrocellulose and probed with an affinity-purified GAP-43 antibody. The GAP-43 immunoreactivity (Fig. 5, lanes 1,2) comigrates with the 48-kD ADP-ribosylated protein (lanes 3, 4). The stimulation of this protein was quantified indicating that the $48-\mathrm{kD}$ protein is modestly stimulated by $5 \mathrm{~mm} \mathrm{SNP} \mathrm{(20 \pm 3 \% ;n=5)} \mathrm{and} \mathrm{by} 10 \mathrm{~mm}$ Sin-1 $(29 \pm 6 \% ; n=5)$.

\section{Discussion}

NO STIMULATES ADP RIBOSYLATION OF PROTEINS IN HIPPOCAMPAL SYNAPTOSOMES

The present study demonstrates the ADP ribosylation of several synaptic proteins, complementing previous studies (Duman et al. 1991; Williams et al. 1992). Stimulation of ADP ribosylation of proteins of apparent molecular masses of $74,54,51$, 48 , and $42 \mathrm{kD}$ resulted from the addition of either of two different NO donors. As the two donors are structurally dissimilar compounds with different decomposition products, the observed stimulation was likely owing to the release of NO. This is further supported by experiments that demonstrated that ferricyanide and light-inactivated SNP did not stimulate ADP ribosylation (Fig. 1, lanes 5,6). In addition, the experiments in which $1 \mathrm{mM}$ or $10 \mathrm{mM}$ Sin-1 was combined with the superoxide anion quenching system of SOD/CAT showed that the production of superoxide anion did not contribute to the stimulation of ADP ribosylation by Sin-1.

\section{THE OBSERVED LABELING IS THE RESULT OF ADP RIBOSYLATION}

Given the controversies in the ADP-ribosylation literature surrounding the validity of claims that NO stimulates ADP ribosylation of proteins (McDonald and Moss 1993), it is perhaps most significant that we have demonstrated that in the

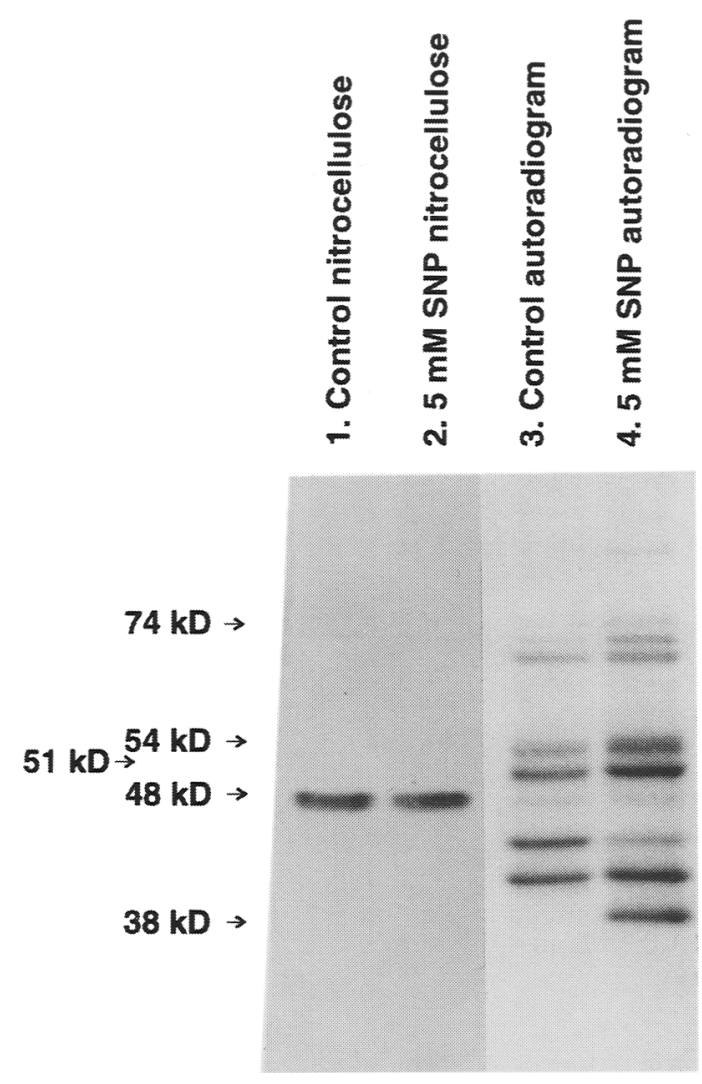

Figure 5: GAP-43 immunoreactivity comigrates with a 48-kD ADP-ribosylated substrate. GAP-43 immunoreactivity determined by Western blot analysis is shown in lanes 1 and 2. The corresponding autoradiogram (lanes $3,4)$ that was exposed to the nitrocellulose in lanes 1 and 2 shows the pattern of NO-stimulated ADP ribosylation, indicating that the GAP-43 immunoreactivity comigrates with the $48-\mathrm{kD}$ protein.

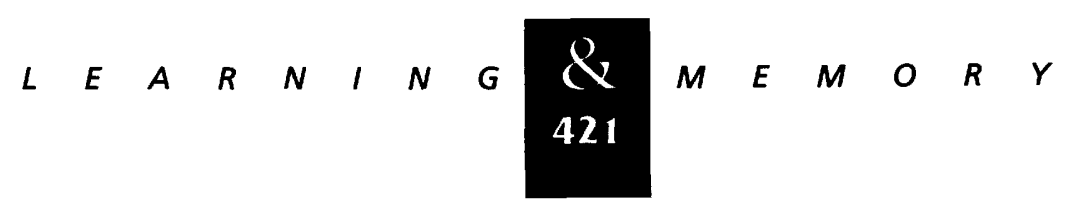


presence of $1 \mathrm{~mm}$ Sin-1, the nicotinamide moiety was not added to the proteins at $74,54,51,48$, and $42 \mathrm{kD}$. It was, however, added to the prominently labeled $38-\mathrm{kD}$ protein and the faintly labeled protein at 33 and $30 \mathrm{kD}$. These data suggest that the $30-, 33-$, and 38-kD proteins were not the substrates of ADP ribosylation in the presence of $1 \mathrm{~mm}$ Sin-1, whereas the labeling of proteins at 74,54 , 51,48 , and $42 \mathrm{kD}$ likely represents true ADP ribosylation.

\section{TISSUE DISTRIBUTION AND SUBCELLULAR}

\section{LOCALIZATION}

Two proteins that appeared to be brain specific were those at 54 and $74 \mathrm{kD}$, both of which were absent from all of the non-neural tissues examined. Many of the proteins that were ADP-ribosylated in hippocampal synaptosomes, including those at $38,42,46$, and $51 \mathrm{kD}$, appeared in other tissues as well. The ADP ribosylation of many of these proteins was stimulated by the NO donor SNP. These observations raise the possibility that ADP ribosylation may be a downstream effector of NO's participitation in immune responses or in smooth muscle relaxation. Lack of brain specificity of some of the substrates, however, does not necessarily imply that the proteins are not important for brain function. For example, Greengard and coworkers found that cAMP stimulated PKA to phosphorylate its regulatory subunit in the brain (Lohmann et al. 1980; Walter and Greengard 1981). The type II regulatory subunit is present in the heart, and its phosphorylation by PKA is stimulated by cAMP there as well (Lohmann et al. 1980). Thus, the substrates common to both neural and non-neural tissues may be important regulatory elements for signal transduction events.

The synaptosome preparation of Carlin et al. (1980) used in these studies is made up primarily of sealed-off presynaptic terminals with a PSD from a ruptured postsynpatic cell attached (Kennedy et al. 1990). The enrichment of many of the substrates in the non-PSD fraction suggests that the proteins may be presynaptic and further increases the likelihood that NO can act as a retrograde messenger.

\section{IDENTITY OF THE SUBSTRATES}

Others (Duman et al. 1991) have suggested that the 42 - and $45-\mathrm{kD}$ (in our experiments, $46-\mathrm{kD}$ ) proteins correspond to the isoforms of $\mathrm{G}_{\mathrm{S} \alpha}$. This conclusion was based on the observed similarities between the patterns of peptides in one-dimensional gels resulting from $\mathrm{V}-8$ protease digestion of proteins that had been labeled with cholera toxin and those that had been labeled by endogenous ADPRTs. The present studies indicate that GAP-43 immunoreactivity comigrates with a $48-\mathrm{kD}$ labeled protein that is stimulated by NO. This result is consistent with the reports of Zweirs and co-workers that GAP-43 is ADP-ribosylated in response to NO (Coggins et al. 1993; Philibert and Zweirs 1995). McDonald and Moss (1993) have shown previously that the $39-\mathrm{kD}$ protein GAPDH shows stimulation properties similar to the $38-\mathrm{kD}$ protein described here.

\section{MAGNITUDE OF STIMULATION}

The largest stimulation observed was a doubling of the labeling of the $74-\mathrm{kD}$ band in the presence of $5 \mathrm{~mm}$ SNP compared with control. The stimulation observed for soluble guanylyl cyclase, arguably the best characterized downstream effector of NO, is orders of magnitude greater than that reported here for the ADPRTs (Southam and Garthwaite 1991). The difference suggests the possibility that soluble guanylyl cyclase might be the primary target of NO, whereas ADPRTs may play a modulatory role. The range of concentrations of NO donors that stimulate the two enzymes are similar, however, suggesting that both targets (guanylyl cyclase and ADPRT) may be stimulated upon physiological release of NO.

Another possibility is that NO acts synergistically with other, as-yet-unidentified second messengers to maximally stimulate the ADPRTs. The situation might be similar to that for protein kinase C (PKC). PKC isoforms are synergistically stimulated by multiple lipids, some of which have only modest effects when applied alone (McPhail et al. 1984; Bell and Burns 1991; Shinomura et al. 1991).

\section{IMPLICATIONS FOR SYNAPTIC PLASTICITY}

Our earlier experiments failed to support a role for CGMP as the downstream effector of NO during LTP (Schuman and Madison 1994), although others have suggested a role (Zhuo et al. 1994a,b; Arancio et al. 1995; but see Selig et al. 1996). The relative amount of NO-stimulated ADP ribosylation

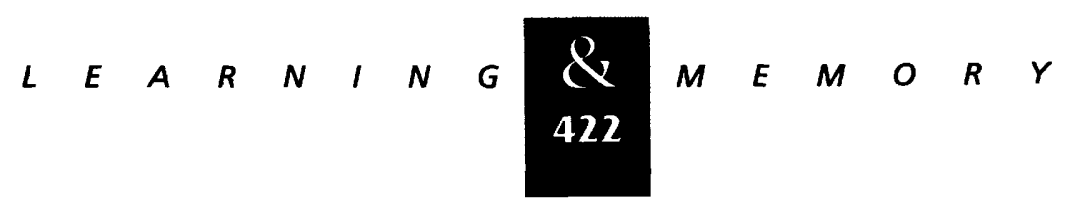


demonstrated under the present experimental conditions, however, is modest for most substrates examined. This suggests that there may be additional routes by which NO influences synaptic function, one of which may be the direct nitrosylation of presynaptic vesicle proteins (Meffert et al. 1996). Electrophysiological studies of LTP have shown that inhibitors of ADPRT can block LTP (Schuman and Madison 1994). Might any of the NO-stimulated proteins observed in this study contribute to LTP? A previous study observed that prior LTP induction reduced the amount of SNP-stimulated ADP ribosylation that could be elicited (Duman et al. 1993). We attempted to determine whether the same inhibitors that prevented LTP had an effect on the NO-stimulated ADP ribosylation of the hippocampal synaptic proteins. We were unable to examine one of the ADPRT inhibitors used in the LTP studies, phylloquinone, as it required an organic solvent to dissolve it. Nonetheless, one inhibitor, nicotinamide, significantly inhibited the ADP ribosylation of the $42-$ and $51-\mathrm{kD}$ proteins at concentrations similar to those that prevented LTP. Taken together with previous studies, these data show that NO released during the induction of synaptic plasticity may modify synaptic proteins by ADP ribosylation. Determining the identity of ADPribosylation substrates and how the ADP-ribosylation pathway may interact with other NO effectors and other signal transduction pathways will be the focus of future studies.

\section{Acknowledgments}

We thank A. Beate Oestreicher for generously providing the GAP-43 antibody and to Mary Kennedy for much advice and discussion. This work was supported by the NIH and by monies from the Alfred P. Sloan Foundation, John Merck Fund, and the PEW Charitable Trusts (all to E.M.S.).

The publication costs of this article were defrayed in part by payment of page charges. This article must therefore be hereby marked "advertisement" in accordance with 18 USC section 1734 solely to indicate this fact.

\section{References}

Arancio, O., E.R. Kandel, and R.D. Hawkins. 1995. Activity-dependent long-term enhancement of transmitter release by presynaptic $3^{\prime}, 5^{\prime}$-cyclic GMP in cultured hippocampal neurons. Nature 376: 74-80.

Bell, R.M. and D.J. Burns. 1991. Lipid activation of protein kinase C. J. Biol. Chem. 266: 4661-4664.

Benowitz, L.I., N.I. Perrone-Bizzozero, and S.P. Finklestein.
1987. Molecular properties of the growth-associated protein GAP-43 (B-50). J. Neurochem. 48: 1640-1647.

Bradford, M. 1976. A rapid and sensitive method for the quantitation of microgram quantities of protein utilizing the principle of protein-dye binding. Anal. Biochem. 72: 248-254.

Brüne, B. and E.G. Lapetina. 1989. Activation of a cytosolic ADP-ribosyltransferase by nitric oxide-generating agents. J. Biol. Chem. 264: 8455-8458.

1990. Properties of a novel nitric oxide-stimulated ADP-ribosyltransferase. Arch. Biochem. Biophys. 279: 286-290.

Carlin, R.K., D.J. Grab, R.S. Cohen, and P. Siekevitz. 1980. Isolation and characterization of postsynaptic densitites from various brain regions: Enrichment of different types of postsynaptic densities. J. Cell Biol. 86: 831-843.

Cleaver, J.E. and W.F. Morgan. 1991. Poly(ADP-ribose) polymerase: A perplexing participant in cellular responses to DNA breakage. Mutat. Res. 257: 1-18.

Coggins, P.J., K. McLean, A. Nagy, and H. Zwiers. 1993. ADP-ribosylation of the neuronal phosphoprotein B-50/GAP-43. J. Neurochem. 60: 368-371.

Dimmeler, S., F. Lottspeich, and B. Brüne. 1992. Nitric oxide causes ADP-ribosylation and inhibition of glyceraldehyde-3-phosphate dehydrogenase. J. Biol. Chem. 267: 16771-16774.

Duman, R.S., R.T. Terwilliger, and E.J. Nestler. 1991. Endogenous ADP-ribosylation in brain: Initial characterization of substrate proteins. J. Neurochem. 57: 2124-2132.

1993. Alterations in nitric-oxide stimulated endogenous ADP-ribosylation associated with long-term potentiation in the rat hippocampus. J. Neurochem. 61: $1542-1545$.

Garthwaite, J. and C.L. Boulton. 1995. Nitric oxide signalling in the central nervous system. Annu. Rev. Physiol. 57: 683-706.

Garthwaite, J., S.L. Charles, R. Chess-Williams. 1988. Endothelium derived relaxing factor release on activation of NMDA receptors suggests role as intercellular messenger in the brain. Nature 336: 385-388.

Gierschik, P. 1992. ADP-ribosylation of signal-transducing guanine nucleotide-binding proteins by pertussis toxin. Curr. Top. Microbiol. Immunol. 175: 69-96.

Gower, H. and R. Rodnight. 1982. Intrinsic protein phosphorlyation in synaptic plasma membrane fragments from the rat: General characteristics and migration behavior on polyacrylamide gels of the main phosphate acceptors. Biochim. Biophys. Acta 716: 45-52.

$$
\begin{array}{lllllllllllllll}
\mathcal{E} & E & A & R & N & I & N & G & \begin{array}{c}
\mathcal{N} \\
423
\end{array} & E & M & O & R & Y
\end{array}
$$


Kennedy, M.B., M.K. Bennett, R.F. Bulleit, N.E. Erondu, V.R. Jennings, S.G. Miller, S.S. Molloy, B.L. Patton, and L.J. Schenker. 1990. Structure and regulation of type II calcium/calmodulin-dependent protein kinase in central nervous system neurons. Cold Spring Harbor Symp. Quant. Biol. 55: 101-110.

Kots, A.Y., A.V. Skurat, E.A. Sergienko, T.V. Bulargina, and E.S. Severin. 1992. Nitroprusside simulates the cysteine-specific mono (ADP-ribosylation) of glyceraldehyde-3-phosphate dehydrogenase from human erythrocytes. FEBS J. 300: 9-12.

Laemmli, U.K. 1970. Cleavage of structural proteins during the assembly of the head of bacteriophage T4. Nature 227: 680-685.

Lei, S.Z., Z.H. Pan, S.K. Aggarwal, H.V. Chen, J. Hartman, N.J. Sucher, and S.A. Lipton. 1992. Effect of nitric oxide production on the redox modulatory site of the NMDA receptor-channel complex. Neuron 8: 1087-1099.

Lohmann, S.M., U. Walter, and P. Greengard. 1980. Identification of endogenous substrate proteins for cAMP-dependent protein kinase in bovine brain. J. Biol. Chem. 255: 9985-9299.

Lowry, O.H., N.J. Rosebrough, A.L. Farr, and R.J. Randall. 1951. Protein measurement with the Folin phenol reagent. J. Biol. Chem. 193: 265-275.

McDonald, L.J. and J. Moss. 1993. Stimulation by nitric oxide of an NAD linkage to glyceraldehyde-3-phosphate dehydrogenase. Proc. Natl. Acad. Sci. 90: 6238-6241.

McPhail, L.C., C.C. Clayton, and R. Snyderman. 1984. A potential second messenger role for unsaturated fatty acids: Activation of $\mathrm{Ca}^{2+}$-dependent protein kinase. Science 224: 622-625.

Meffert, M.K., N.C. Calakos, and R.H. Scheller. 1996. Nitric-oxide modulates synaptic vesicle docking/fusion reactions. Neuron 16: 1229-1236.

Oestreicher, A.B., M.V. Duin, H. Zweirs, and W.H. Gispen. 1984. Cross-reaction of anti-rat B-50: Characterization and isolation of a "B-50 phosphoprotein" from bovine brain. J. Neurochem. 43: 935-943.

Okayama, H., K. Ueda, and O. Hayashi. 1978. Purification of ADP-ribosylated nuclear proteins by covalent chromatography on dihyroxyboryl polyacrylamide beads and their characterization. Proc. Natl. Acad. Sci. 75: 1111-1115.

Philibert, K. and H. Zweirs. 1995. Evidence of multisite ADP-ribosylation of neuronal phosphoprotein B-50/GAP-43. Mol. Cell. Biochem. 149/150: 183-190.

Rankin, P.W., E.L. Jacobson, R.C. Benjamin, J. Moss, and M.K. Jacobson. 1989. Quantitative studies of inhibitors of ADP-ribosylaton in vitro and in vivo. J. Biol. Chem.

264: 4312-4317.
Schuman, E.M. and D.V. Madison. 1994. Nitric oxide and synaptic function. Annu. Rev. Neurosci. 17: 153-183.

Schuman, E.M., M.K. Meffert, H. Schulman, and D.V. Madison. 1994. A potential role for an ADP-ribosyltransferase in hippocampal long-term potentiation. Proc. Natl. Acad. Sci. 91: 11958-11962.

Selig, D.K., M.R. Segal, D. Liao, R.C. Malenka, R. Malinow, R.A. Nicoll, and J.E. Lisman. 1996. Examination of the role of cGMP in long-term potentiation in the CA1 region of the hippocampus. Learn. \& Mem. 3: 42-48.

Serventi, I.M., J. Moss, and M. Vaughan. 1992. Enhancement of cholera toxin-catalyzed ADP-ribosylation by guanine nucleotide-binding proteins. Curr. Top. Microbiol. Immunol. 175: 43-67.

Shinomura, T., Y. Asaoka, M. Oka, K. Yoshida, and Y. Nishizuka. 1991. Synergistic action of diacylglycerol and unsaturated fatty acid for protein kinase $C$ activation: Its possible implications. Proc. Natl. Acad. Sci. 88: 5149-5153.

Southam, E. and J. Garthwaite. 1991. Comparative effects of some nitric oxide donors on cyclic GMP levels in rat cerebellar slices. Neurosci. Lett. 130: 107-111.

Ueda, K. and O. Hayaishi. 1985. ADP-ribosylation. Annu. Rev. Biochem. 54: 73-100.

Walter, U. and P. Greengard. 1981. Cyclic AMP-dependent and cyclic GMP-dependent protein kinases of nervous tissue. Curr. Top. Cell. Regul. 19: 219-256.

Williams, M.B., X. Li, X. Gu, and R.S. Jope. 1992. Modulation of endogenous ADP-ribosylation in rat brain. Brain Res. 592: 49-56.

Zhang, J. and S. Snyder. 1992. Nitric oxide stimulates auto-ADP-ribosylation of glyceraldehyde-3-phosphate dehydrogenase. Proc. Natl. Acad. Sci. 89: 9382-9385.

Zhang, J., V.L. Dawson, T.M. Dawson, and S.J. Snyder. 1994. Nitric oxide activation of poly(ADP-ribose) synthetase in neurotoxicity. Science 263: 687-689.

Zhuo, M., Y.H. Hu, C. Schultz, E.R. Kandel, and R.D. Hawkins. 1994a. Role of guanylyl cyclase and cGMP-dependent protein-kinase in long-term potentiation. Nature 368: 635-639.

Zhuo, M., E.R. Kandel, and R.D. Hawkins. 1994b. Nitric-oxide and CGMP can produce either synaptic depression or potentiation depending on the frequency of presynaptic stimulation in the hippocampus. NeuroReport 5L: 1033-1036.

Received October 29, 1996; accepted in revised from January 23, 1997.

$$
\text { ……… }
$$




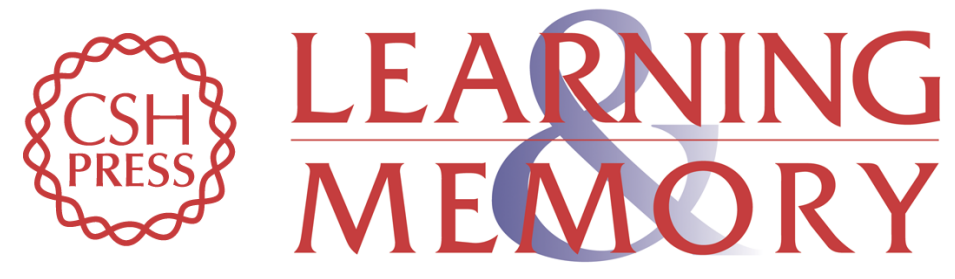

\section{Modification of hippocampal synaptic proteins by nitric oxide-stimulated ADP ribosylation.}

B M Sullivan, S Wong and E M Schuman

Learn. Mem. 1997, 3:

Access the most recent version at doi:10.1101//m.3.5.414

References This article cites 42 articles, 15 of which can be accessed free at: http://learnmem.cshlp.org/content/3/5/414.full.html\#ref-list-1

License

Email Alerting Receive free email alerts when new articles cite this article - sign up in the box at the Service top right corner of the article or click here. 